\title{
Protective effect of selenium against cisplatin-induced nasopharyngeal cancer in male albino rats
}

\author{
$\mathrm{KAN} \mathrm{ZHU}^{1 *}$, LEI JIANG ${ }^{2 *}, \mathrm{YUN} \mathrm{CHU}^{3}$ and YONG-SHENG ZHANG ${ }^{1}$ \\ Departments of ${ }^{1}$ Otorhinolaryngology, ${ }^{2}$ Neurosurgery and ${ }^{3}$ Surgery, \\ Wuxi No. 2 People's Hospital Affiliated to Nanjing Medical University, Wuxi, Jiangsu 214002, P.R. China
}

Received July 23, 2015; Accepted September 9, 2016

DOI: $10.3892 / \mathrm{ol} .2016 .5346$

\begin{abstract}
The present study evaluated the protective effect of selenium against cisplatin-induced nasopharyngeal cancer in the cardiac tissue of adult rats. Male Wistar rats were divided into 4 groups of 6 rats each. Different combinations of selenium and cisplatin were administered for 45 days, following which the animals were sacrificed and the nasopharyngeal tissue was surgically removed. Lipid peroxidation, reduced glutathione, and the antioxidant enzymes superoxide dismutase (SOD), catalase and lactate dehydrogenase (LDH) were measured. Apoptotic-related gene (p53, bax and caspase 3) mRNA expression was determined using quantitative polymerase chain reaction. Caspase 3 activity was also measured in all the groups. The results demonstrated that selenium significantly reduced the levels of malondialdehyde. The levels of glutathione, SOD, LDH and catalase significantly increased following selenium treatment. Relative mRNA expression (p53, bax and caspase 3) was significantly reduced in the cisplatin-treated rats, but it significantly increased following selenium treatment. The anticancer activity of selenium was also investigated in HK1cells. Fluorescence and confocal microscopy were used to analyze apoptosis and reactive oxygen species. The protective effect of selenium was also evident through caspase 3 activity, which significantly increased following selenium treatment. Taken together, these results indicate that selenium may be beneficial against cisplatin-induced nasopharyngeal cancer.
\end{abstract}

Correspondence to: Dr Yong-Sheng Zhang, Department of Otorhinolaryngology, Wuxi No. 2 People's Hospital Affiliated to Nanjing Medical University, 68 Zhongshan Road, Wuxi, Jiangsu 214002, P.R. China

E-mail: yongshengzhang17@hotmail.com

${ }^{*}$ Contributed equally

Key words: selenium, cisplatin, rats, antioxidant, mRNA

\section{Introduction}

Selenium, an essential biological trace element, has received considerable attention as an important micronutrient for humans. Selenium serves a role in several cellular and physiological processes, including thyroid hormone production and immune responses (1). It has been reported that selenium has antioxidant properties (2). Food and drink are the primary natural sources of selenium. High levels of selenium are present in cereals, seafood and meat products, whereas there is little found in vegetables, milk or fruits (3). Selenium deficiency has been associated with several degenerative diseases (4). Selenium has been widely used to treat several pathophysiological conditions, including cervical, renal and liver cancer (5).

Nasopharyngeal carcinoma is an endemic disease in South Asia. There are several conventional treatments available, including radiotherapy. Chemotherapy has gained importance in the treatment of nasopharyngeal carcinoma (6). However, the complications are high. Chemotherapy treatment frequently fails due to multidrug resistance and cancer treatment requires selective action on the targeted site (6). Cisplatin is a widely used therapeutic agent that acts as a radiation sensitizer and a cytotoxic compound (6). Cisplatin-acquired resistance in patients may lead to the failure of chemotherapy treatment (6). Drug resistance and the establishment of cisplatin-resistant cells are considered to be possible ways to understand the chemoresistance mechanism (6).

To the best of our knowledge, cisplatin-resistant nasopharyngeal carcinoma cell establishment and associated studies are limited. Studies on selenium treatment against cisplatin-induced nasopharyngeal cancer are also limited. The ability of selenium to neutralize the toxicity of cisplatin in the nasopharyngeal tissue has yet to be investigated. The present study examines the impact of selenium on cisplatin-induced toxicity.

\section{Materials and methods}

Materials. Dimethyl sulfoxide was purchased from SigmaAldrich (Merck Millipore, Darmstadt, Germany). Dulbecco's modified Eagle's medium, fetal bovine serum (FBS), penicillin-streptomycin and trypsin-ethylenediaminetetraacetic 
acid were obtained from Welgene, Inc. (Gyeongsan-si, South Korea). Acridine orange (AO), ethidium bromide (EB) and 2',7'-dichlorofluorescein diacetate (DCFH-DA) were purchased from Santa Cruz Biotechnology, Inc. (Dallas, TX, USA). Primers were obtained from Macrogen Inc. (Seoul, South Korea).

Animals. Healthy, male, albino rats were purchased from the Department of Otorhinolaryngology, Jiangsu Provincial People's Hospital Affiliated to Nanjing Medical University (Nanjing, China). Those weighing 160-180 g were selected for the present study. The rats were kept in polypropylene cages, at a temperature of $25 \pm 0.5^{\circ} \mathrm{C}$, at a relative humidity of $60 \pm 5 \%$ and at a photoperiod of $12 \mathrm{~h} /$ day. The male albino rats were grouped into 4 groups of 6 rats each.

Experimental induction of cancer. The application of carcinogens was achieved by means of cisplatin treatment prior to the experiments. Cisplatin $(10 \mu \mathrm{g})$ was administered for 45 days for the induction of diabetes with final tumor incidences close to $100 \%$.

Treatment. The experimental groups were designated as follows: Group I, normal saline (10 $\mu \mathrm{l})$; Group II, $10 \mu \mathrm{g}$ cisplatin; Group III, $10 \mu \mathrm{g}$ selenium $+10 \mu \mathrm{g}$ cisplatin; and Group IV $20 \mu \mathrm{g}$ selenium $+20 \mu \mathrm{g}$ cisplatin. The drug was administered intraperitoneally for 45 days. The dose level and duration of the experiment was selected based on our preliminary study. The preliminary study was conducted with a different dose level (range, 1-100 $\mu \mathrm{g}$ ). The animals were sacrificed by decapitation, and nasopharyngeal tissue was surgically removed. Animal tissues were homogenized using a Potter-Elvehjem glass-Teflon homogenizer and a Dounce hand homogenizer (Sigma-Aldrich; Merck Millipore). This method is rapid and poses little risk to proteins, other than the release of proteases from other cellular compartments. Proteolytic degradation was reduced by adding protease inhibitors to the homogenization buffers. The prepared tissue homogenate was used immediately in subsequent investigations.

\section{In vivo studies.}

Determination of lipid peroxidation. Lipid peroxidation (LPO) was determined using the Lipid Peroxidation (MDA) assay kit (ab118970; Abcam, Cambridge, MA, USA). This was based on the spectrophotometric method of Pandurangan et al (7). Malondialdehyde (MDA) was measured by determining the thiobarbituric acid reactive species. The absorbance of the resulting product was measured at $534 \mathrm{~nm}$ (Cary $100 \mathrm{UV}-\mathrm{Vis}$ spectrophotometer; Agilent Technologies, Inc., Santa Clara, CA, USA).

Determination of reduced glutathione. Glutathione (GSH) level was measured using the gluathione assay kit (Abcam). This was based on the spectrophotometric method of Pandurangan et al (7). The yellow product color was measured at $405 \mathrm{~nm}$ (Cary $100 \mathrm{UV}-\mathrm{Vis}$ spectrophotometer; Agilent Technologies, Inc.).

Determination of superoxide dismutase (SOD) and catalase enzyme activities. SOD, catalase and lactate dehydrogenase
(LDH) enzyme activities were determined using the antioxidant enzyme assay kit method (Abcam) which was based on the method of Pandurangan et al (7).

Quantitative polymerase chain reaction ( $q P C R$ ). The $\mathrm{qPCR}$ was performed using a cDNA equivalent of $10 \mathrm{ng}$ total RNA from each sample, withspecific primers for p53 (forward, 5'-TAACAGTTCCTGCATGGGCGGC-3' and reverse, 5'-AGGACAGGCACAAACACGCACC-3'), bax (forward, 5'-TGGAGCTGCAGAGGATGATTG-3' and reverse, 5'-GAA GTTGCCGTCAGAAAACATG-3'), caspase 3 (forward, 5'-TTAATAAAGGTATCCATGGAGAACACT-3' and reverse, 5'-TTAGTGATAAAAATAGAGTTCTTTTGTGAG-3') and a housekeeping gene, glyceraldehyde 3-phosphate dehydrogenase (forward, 5'-GGTCACCAGGGCTGCTTTT-3' and reverse, 5'-ATC TCGCTCCTGGAAGATGGT-3'). Time, temperature and cycles were performed as previously described (8). The reaction was performed in a $10 \mu \mathrm{l}$ reaction volume using SYBR Green Master mix (Bioneer Corporation, Daejeon, Korea) according to the manufacturer's protocol (8).

Caspase activity assay. Caspase 3 enzyme activity was measured using an activity assay kit (Sigma-Aldrich; Merck Millipore) based on the method of Muthuraman (9).

\section{In vitro studies.}

Cell culture. HK1 cells were obtained from the American Type Culture Collection (Manassas, VA, USA). 10\% FBS and $1 \%$ antibiotics (1\% penicillin-streptomycin) were used for cell growth. The cells were grown to $90 \%$ confluence in a $\mathrm{CO}_{2}$ incubator at $37^{\circ} \mathrm{C}$ with $5 \% \mathrm{CO}_{2}$.

Fluorescence microscopy. The HK1 cells $\left(2.5 \times 10^{4}\right)$ were cultured in 6-well plates and treated for $48 \mathrm{~h}$ with either $10 \mu \mathrm{g} / \mathrm{ml}$ selenium, $10 \mu \mathrm{g} / \mathrm{ml}$ selenium $+10 \mu \mathrm{g} / \mathrm{ml}$ cisplatin or $20 \mu \mathrm{g}$ selenium $+20 \mu \mathrm{g}$ cisplatin. Control cells were incubated with growth medium only. The cells were examined with a fluorescence microscope (10) (Axiovert 2000; Carl Zeiss AG, Oberkochen, Germany).

Confocal laser scanning (CLS) microscopy. The HK1 cells $\left(2.5 \times 10^{4}\right)$ were grown at a volume of $2 \times 10^{4}$ cells/well in 6-well plates. The cells were treated for $48 \mathrm{~h}$ with either $10 \mu \mathrm{g} / \mathrm{ml}$ selenium, $10 \mu \mathrm{g} / \mathrm{ml}$ selenium $+10 \mu \mathrm{g} / \mathrm{ml}$ cisplatin or $20 \mu \mathrm{g}$ selenium $+20 \mu \mathrm{g}$ cisplatin. Control cells were incubated with growth medium only. Cells were stained with EB and AO stains. The cells were viewed immediately under a CLS microscope (1X81 ${ }^{\mathrm{R}}$ Motorized Inverted Microscope; Olympus Corporation, Tokyo, Japan) (10).

Determination of reactive oxygen species (ROS) production. The HK1 cells $\left(2.5 \times 10^{4}\right)$ were cultured in6-well plates and treated for $48 \mathrm{~h}$ with either $10 \mu \mathrm{g} / \mathrm{ml}$ selenium, $10 \mu \mathrm{g} / \mathrm{ml}$ selenium $+10 \mu \mathrm{g} / \mathrm{ml}$ cisplatin or $20 \mu \mathrm{g}$ selenium $+20 \mu \mathrm{g}$ cisplatin. Control cells were incubated with growth medium only. The cells were incubated with $5 \mu \mathrm{M}$ of DCFH-DA in a growth medium (Sigma-Aldrich; Merck Millipore) for $30 \mathrm{~min}$ at $37^{\circ} \mathrm{C}$ and $5 \% \mathrm{CO}_{2}$. The fluorescence was measured at 485/525 $\mathrm{nm}(\mathrm{Ex} / \mathrm{Em})$ based on the method of Muthuraman et al (10) (Axiovert 2000; Carl Zeiss AG). 
Statistical analysis. All values are expressed as the mean \pm standard deviation. Test and control values were compared using the Student's $t$-test (SPSS 16, Statistical Package; SPSS, Inc., Chicago, IL, USA). $\mathrm{P}<0.05$ was considered to indicate a statistically significant difference.

\section{Results}

Effect of selenium on MDA concentration. The effect of selenium on MDA concentration in the male albino rats is demonstrated in Fig. 1. The MDA concentration in the control rats (group I) was $33 \pm 1 \mathrm{nmol} / \mathrm{g}$, whereas it increased to $58 \pm 1.1 \mathrm{nmol} / \mathrm{g}$ in the cisplatin-induced rats (group II). The administration of $10 \mu \mathrm{g} / \mathrm{ml}$ selenium with $10 \mu \mathrm{g} / \mathrm{ml}$ cisplatin (group III) significantly reduced $(49 \pm 1.2 \mathrm{nhmol} / \mathrm{g})$ the concentration of MDA in the rats compared to the control group (group I) (P=0.02132; Fig. 1). The administration of $20 \mu \mathrm{g} / \mathrm{ml}$ selenium with $20 \mu \mathrm{g} / \mathrm{ml}$ cisplatin (group IV) also significantly reduced the concentration of MDA $(37 \pm 1.3 \mathrm{nmol} / \mathrm{g})$ in the rats compared to the control group (group I) $(\mathrm{P}=0.03562$; Fig. 1).

Effect of selenium on level of GSH. The effect of selenium on GSH content in the male albino rats is demonstrated in Fig. 2. The level of GSH in the control rats (group I) was $67 \pm 2 \mathrm{mg} / \mathrm{g}$, whereas it decreased to $36 \pm 1.1 \mathrm{mg} / \mathrm{g}$ in the cisplatin-induced rats (group II). The administration of $10 \mu \mathrm{g} / \mathrm{ml}$ selenium with $10 \mu \mathrm{g} / \mathrm{ml}$ cisplatin (group III) significantly increased $(46 \pm 1.2 \mathrm{mg} / \mathrm{g})$ the level of GSH in the rats compared to the control group (group I) (P=0.4329; Fig. 2). The administration of $20 \mu \mathrm{g} / \mathrm{ml}$ selenium with $20 \mu \mathrm{g} / \mathrm{ml}$ cisplatin (group IV) also significantly increased the level of GSH $(58 \pm 1 \mathrm{mg} / \mathrm{g})$ in the rats compared to the control group (group I) ( $\mathrm{P}=0.02147$; Fig. 2).

Effect of selenium on SOD activity. The effect of selenium on SOD activity in the male albino rats is demonstrated in Fig. 3. The SOD activity in the control rats (group I) was $3.1 \pm 0.1 \mathrm{U} / \mathrm{mg}$, whereas it decreased to $2.1 \pm 0.02 \mathrm{U} / \mathrm{mg}$ in the cisplatin-induced rats (group II). The administration of $10 \mu \mathrm{g} / \mathrm{ml}$ selenium with $10 \mu \mathrm{g} / \mathrm{ml}$ cisplatin (group III) significantly increased the SOD activity in the rats compared to the control group (group I) ( $\mathrm{P}=0.03253$; Fig. 3). The administration of $20 \mu \mathrm{g} / \mathrm{ml}$ of selenium with $20 \mu \mathrm{g} / \mathrm{ml}$ of cisplatin (group IV) also significantly increased the SOD activity $(58 \pm 1 \mathrm{mg} / \mathrm{g})$ in the rats compared to the control group (group I) $(\mathrm{P}=0.03821$; Fig. 3$)$.

Effect of selenium on catalase activity. The effect of selenium on catalase activity in the male albino rats is demonstrated in Fig. 4. The catalase activity in the control rats (group I) was $9.2 \pm 0.1 \mathrm{U} / \mathrm{g}$, whereas it decreased to $5.2 \pm 0.2 \mathrm{U} / \mathrm{g}$ in the cisplatin-induced rats (group II). The administration of $10 \mu \mathrm{g} / \mathrm{ml}$ selenium with $10 \mu \mathrm{g} / \mathrm{ml}$ cisplatin (group III) $(\mathrm{P}=0.02225$; Fig. 4) significantly increased $(6.4 \pm 0.1 \mathrm{U} / \mathrm{g})$ the catalase activity in the rats compared to the control group (group I). The administration of $20 \mu \mathrm{g} / \mathrm{ml}$ selenium with $20 \mu \mathrm{g} / \mathrm{ml}$ cisplatin (group IV) also significantly increased the catalase activity $(7.9 \pm 0.2 \mathrm{U} / \mathrm{g})$ in the rats compared to the control group (group I) (P=0.03312; Fig. 4).

Effect of selenium on LDH activity. The effect of selenium on $\mathrm{LDH}$ activity in the male albino rats is demonstrated in Fig. 5.

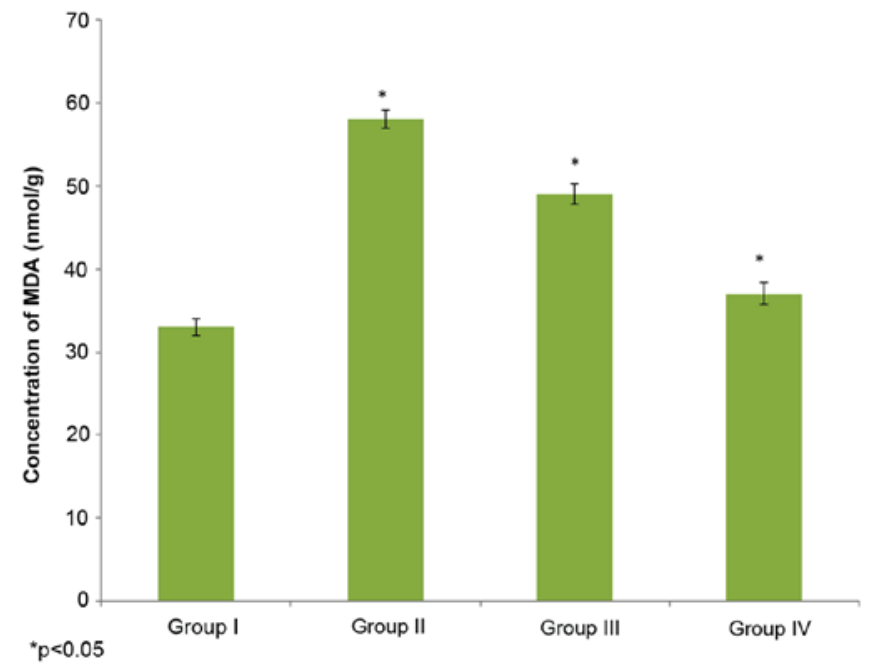

Figure 1. Effect of selenium on lipid peroxidation in nasopharyngeal cancer of male albino rats, as determined by MDA, malondioldehyde, level. The results are presented as $\mathrm{nmol} / \mathrm{g}$ compared with the control. Values are expressed as the mean \pm standard deviation. ${ }^{*} \mathrm{P}<0.05$ vs. control.

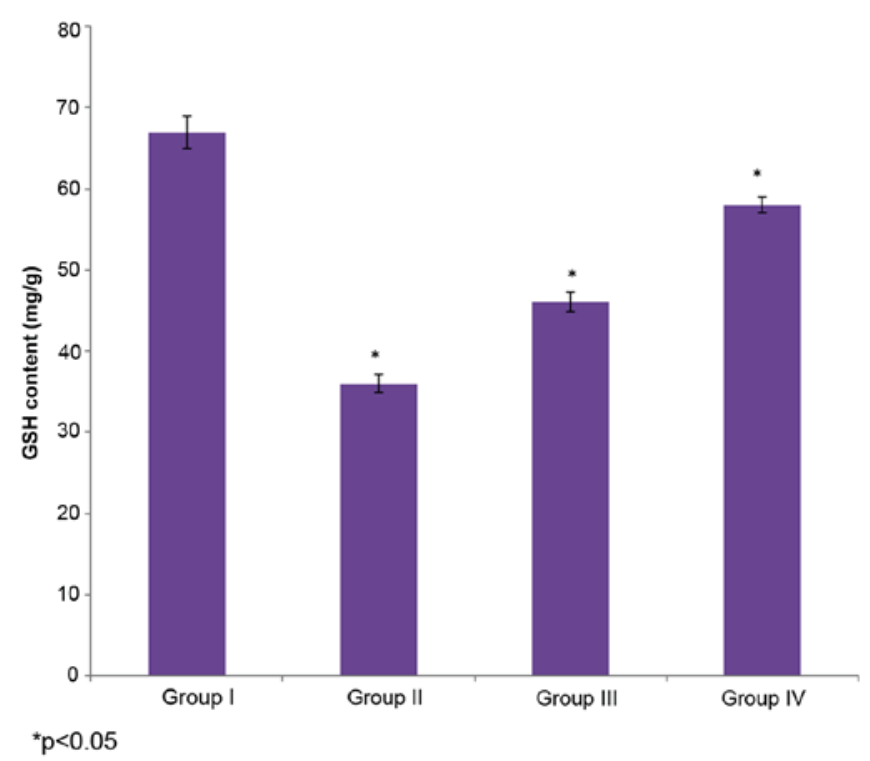

Figure 2. Effect of selenium on GSH, glutathione, levels in the nasopharyngeal cancer of male albino rats. The results are presented as $\mathrm{mg} / \mathrm{g}$ compared with the control. Values are expressed as the mean \pm standard deviation. ${ }^{*} \mathrm{P}<0.05$ vs. control.

The LDH activity in the control rats (group I) was $90 \pm 2 \mathrm{U} / 1$, whereas it increased to $152 \pm 3 \mathrm{U} / 1$ in the cisplatin-induced rats (group II). The administration of $10 \mu \mathrm{g} / \mathrm{ml}$ selenium with $10 \mu \mathrm{g} / \mathrm{ml}$ cisplatin (group III) significantly decreased $(124 \pm 2 \mathrm{U} / \mathrm{l})$ the LDH activity in the rats compared to the control group (group I) ( $\mathrm{P}=0.02412$; Fig. 5). The administration of $20 \mu \mathrm{g} / \mathrm{ml}$ selenium with $20 \mu \mathrm{g} / \mathrm{ml}$ cisplatin (group IV) also significantly decreased LDH activity $(107 \pm 2$ UL-1) in the ratscompared to the control group (group I) $(\mathrm{P}=0.04412$; Fig. 5).

Effect of selenium on mRNA expression. The effect of selenium on mRNA expression in the male albino rats is shown in Fig. 6. The mRNA expression of p53, bax and caspase 3 decreased 


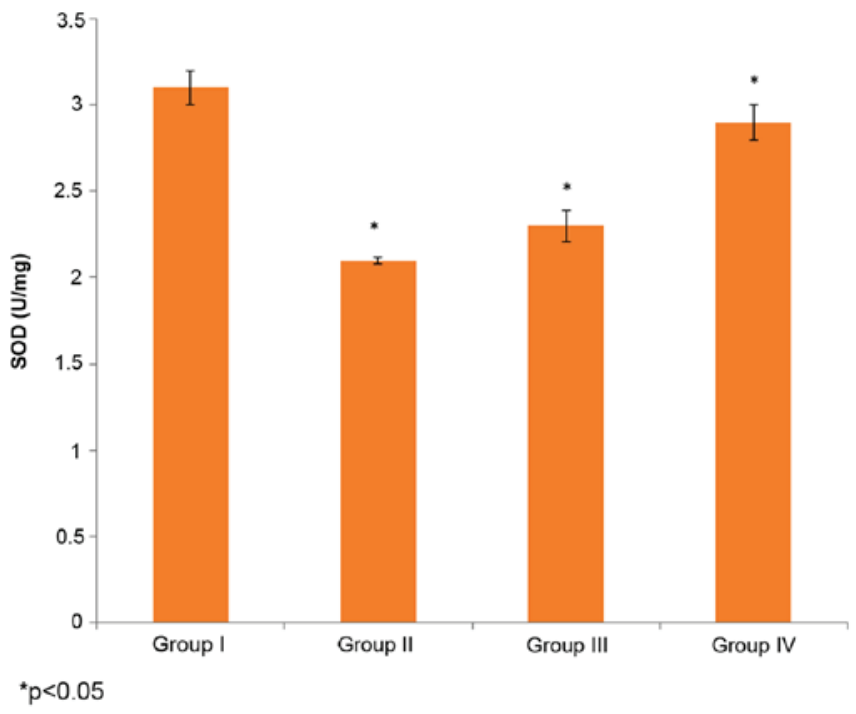

Figure 3. Effect of selenium on SOD, superoxide dismutase, activity in the nasopharyngeal cancer of male albino rats. The results are presented as $\mathrm{U} / \mathrm{mg}$ compared with the control. Values are expressed as the mean \pm standard deviation. ${ }^{*} \mathrm{P}<0.05$ vs. control.

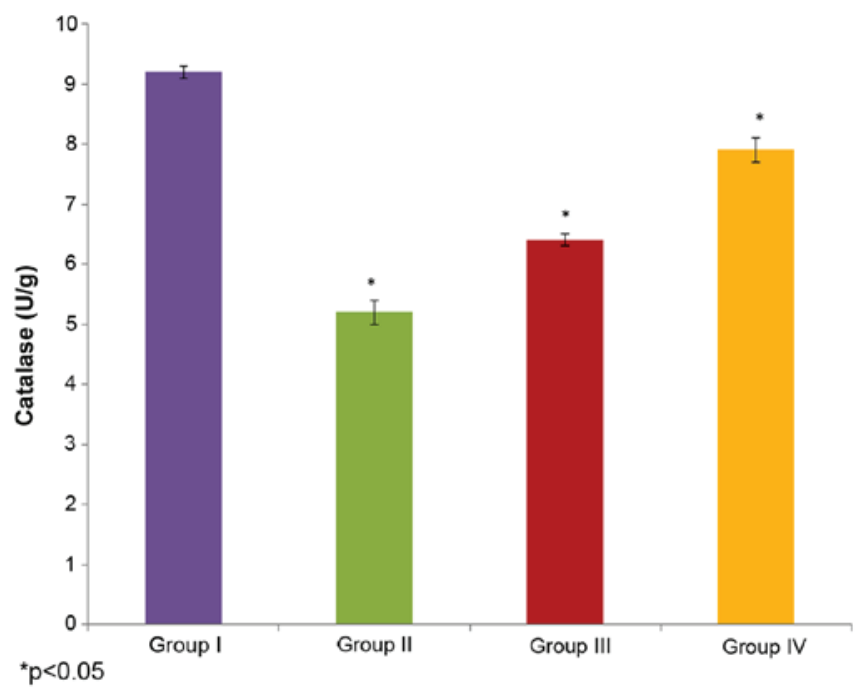

Figure 4. Effect of selenium on catalase activity in the nasopharyngeal cancer of male albino rats. The results are presented as $\mathrm{U} / \mathrm{g}$ compared with the control. Values are expressed as the mean \pm standard deviation. ${ }^{*} \mathrm{P}<0.05$ vs. control.

$0.53-, 0.39$ and 0.48 -fold, in the cisplatin-induced rats (group I) compared with their respective controls (group I). The administration of $10 \mu \mathrm{g} / \mathrm{ml}$ selenium with $10 \mu \mathrm{g} / \mathrm{ml}$ cisplatin (group III) significantly increased mRNA expression of p53, bax and caspase $3(0.42-, 0.27$ - and 0.36 -fold, respectively) in the rats compared to the control group (group I) ( $\mathrm{P}=0.03312$; Fig. 6). The administration of $20 \mu \mathrm{g} / \mathrm{ml}$ of selenium with $20 \mu \mathrm{g} / \mathrm{ml}$ of cisplatin (group IV) significantly increased mRNA expression (0.13-, 0.11- and 0.22-fold, respectively) in the rats compared towith the control group ( $\mathrm{P}=0.05113$; Fig. 6).

Effect of selenium on caspase 3 activity. The effect of selenium on caspase 3 activity in the male albino rats is shown in Fig. 7. The caspase 3 activity decreased to $11 \%$ of the control

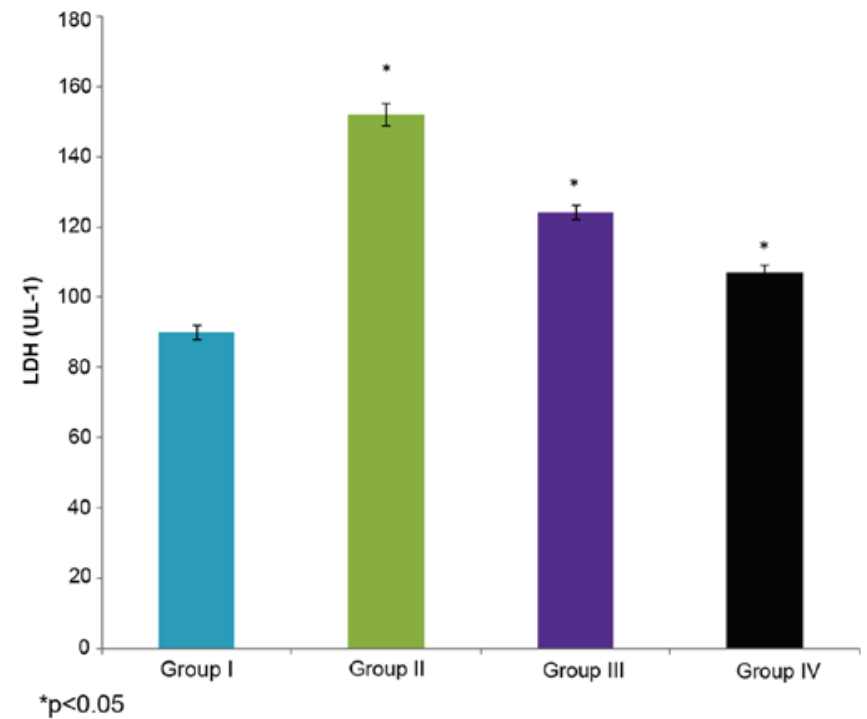

Figure 5. Effect of selenium on LDH, lactate dehydrogenase, activity in the nasopharyngeal cancer of male albino rats. The results are presented as UL-1 compared with the control. Values are expressed as the mean \pm standard deviation. ${ }^{*} \mathrm{P}<0.05$ vs. control.

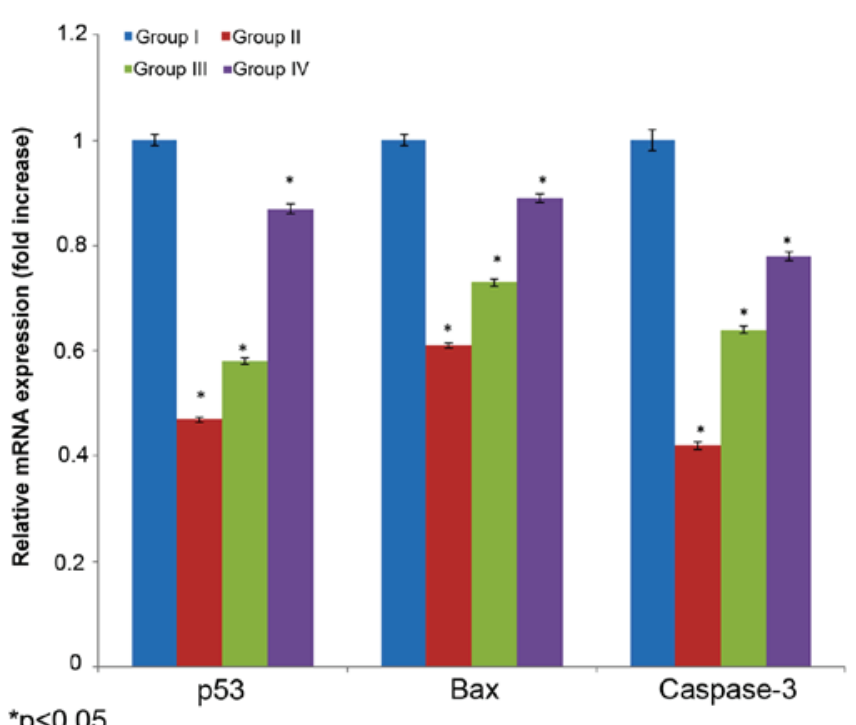

${ }^{*} \mathrm{p}<0.05$

Figure 6. Effect of selenium on apoptotic-related gene mRNA expression in the nasopharyngeal cancer of male albino rats. The results are presented as fold increase compared with the control. Values are expressed as the mean \pm standard deviation. ${ }^{*} \mathrm{P}<0.05$ vs. control.

in the cisplatin-induced rats (group II). The administration of $10 \mu \mathrm{g} / \mathrm{ml}$ selenium with $10 \mu \mathrm{g} / \mathrm{ml}$ cisplatin (group III) significantly increased (17.4\%) the caspase 3 activity in the rats compared to the control group (group I) $(\mathrm{P}=0.04451$; Fig. 7). The administration of $20 \mu \mathrm{g} / \mathrm{ml}$ selenium with $20 \mu \mathrm{g} / \mathrm{ml}$ cisplatin (group IV) also significantly increased the caspase 3 activity $(28.2 \%)$ in the rats compared to the control group (group I) ( $\mathrm{P}=0.04123$; Fig. 7).

Effect of selenium on apoptosis. Microscopy was performed to determine whether the anticancer activity of selenium is associated with the induction of apoptosis, a morphological feature of cell death. Chromatin condensation in the stained 


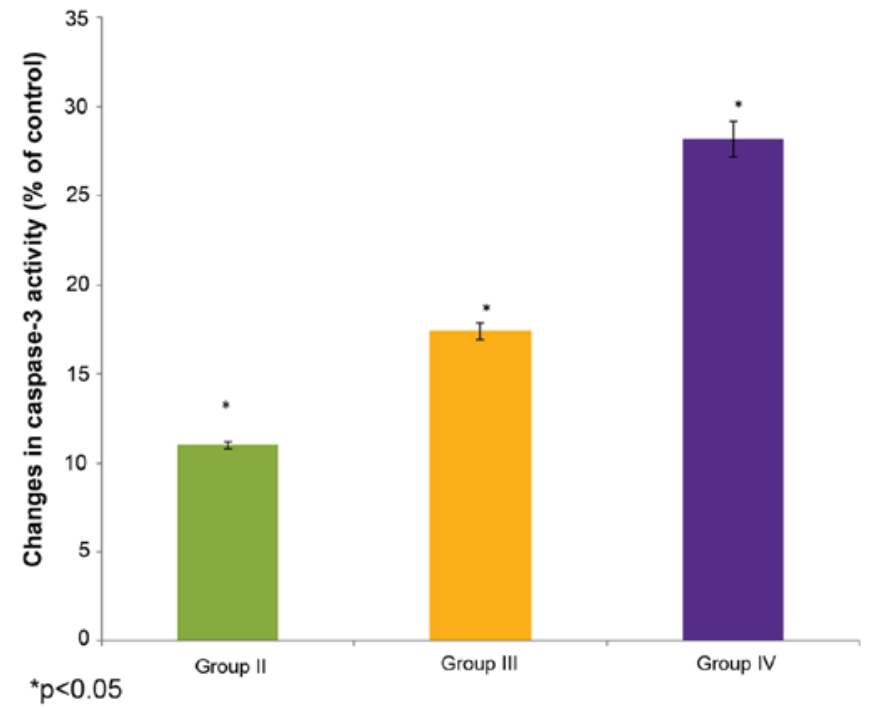

Figure 7. Effect of selenium on caspase 3 activity in the nasopharyngeal cancer of male albino rats. The results are presented as percentage compared with the control. Values are expressed as the mean \pm standard deviation. ${ }^{*} \mathrm{P}<0.05$ vs. control.
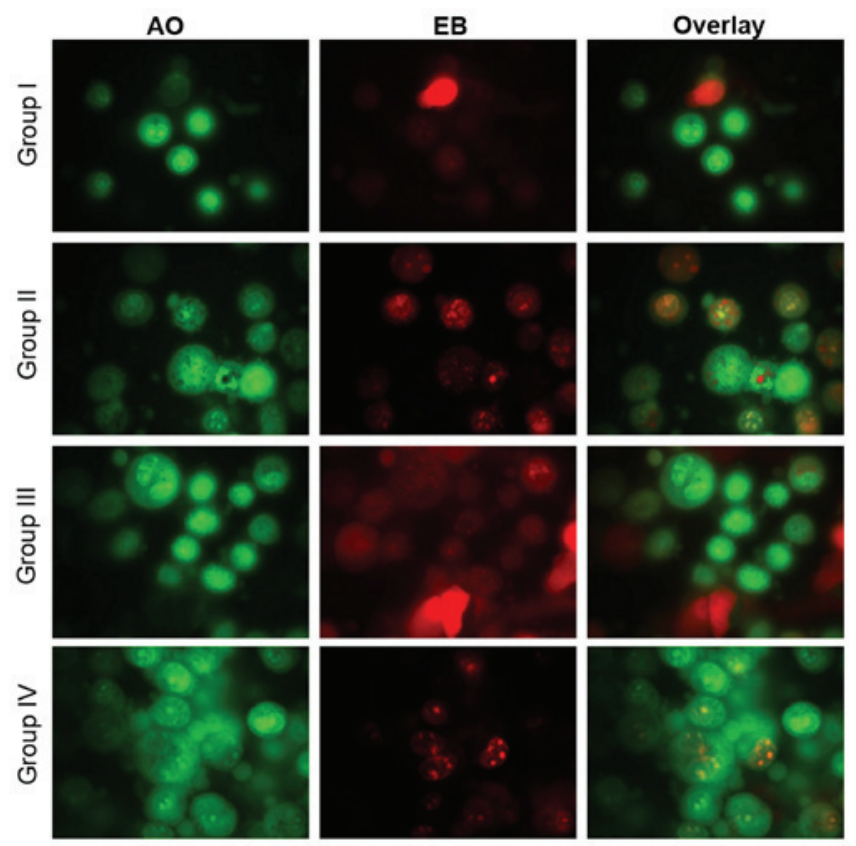

Figure 8. Effect of selenium on apoptosis in nasopharyngeal cancer cells. AO, acridine orange and EB, ethidium bromide, stains are shown. The respective images from three independent fluorescence experiments.

nucleus was used to differentiate viable, apoptotic and necrotic cells. The anticancer activity of cisplatin in the HK1 cells is shown in Figs. 8 and 9. The analysis revealed normal cell size and morphology in the control cells (group I), whereas the cisplatin-incubated HK1 cells demonstrated altered cell morphology, including apoptosis and necrosis (group II). The administration of $10 \mu \mathrm{g} / \mathrm{ml}$ selenium with $10 \mu \mathrm{g} / \mathrm{ml}$ cisplatin (group III) significantly reduced the apoptosis and necrosis of the cells compared to the control group (group II). The administration of $20 \mu \mathrm{g} / \mathrm{ml}$ selenium with $20 \mu \mathrm{g} / \mathrm{ml}$ cisplatin (group IV) ( $\mathrm{P}=0.03421$; Figs. 8 and 9) significantly reduced

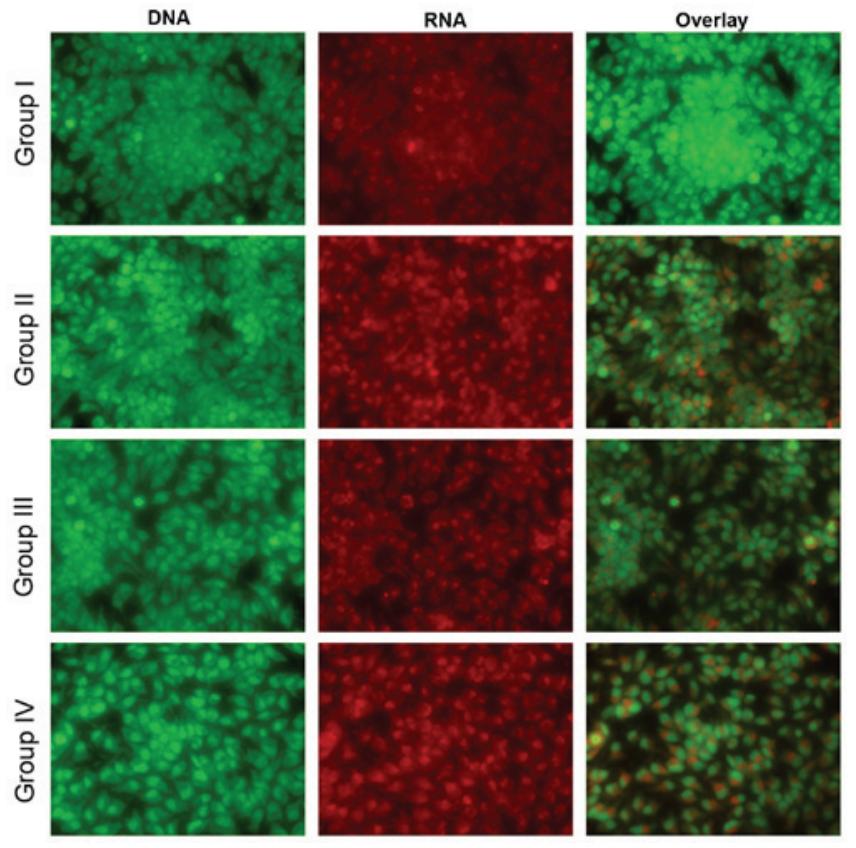

Figure 9. Effect of selenium on apoptosis in the nasopharyngeal cancer cells. The respective images from three independent confocal experiments.

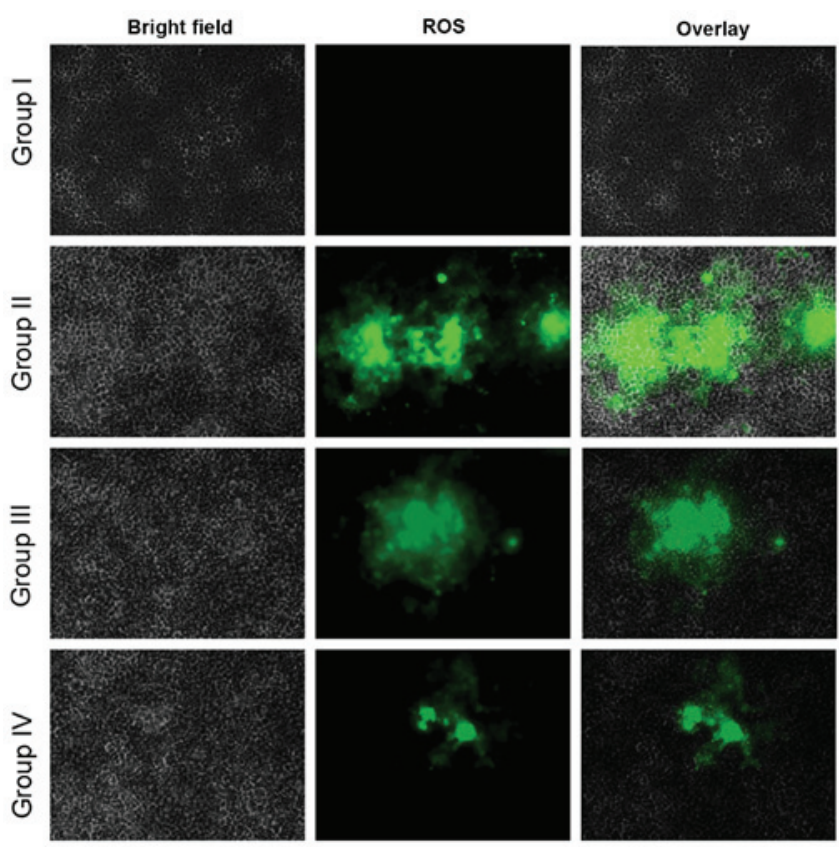

Figure 10. Effect of selenium on ROS, reactive oxygen species, in the nasopharyngeal cancer cells. The respective images from three independent experiments.

the occurrence of apoptosis and necrosis towards normal levels compared to the control group (group II) $(\mathrm{P}=0.03411$; Figs. 8 and 9).

Effect of selenium on reactive oxygen species (ROS) level. ROS play a vital role in facilitating signal transduction processes within the intracellular region (10). The fluorescent probe, DCFH-DA, determined the intracellular ROS generation. Fluorescence studies indicated no green fluorescence intensity of DCF in the control cells (group I), whereas increased levels 
were found in the cisplatin-incubated cells (group II). The administration of $10 \mu \mathrm{g} / \mathrm{ml}$ selenium with $10 \mu \mathrm{g} / \mathrm{ml}$ cisplatin (group III) significantly increased the levels of ROS compared with the control group (II). The administration of $20 \mu \mathrm{g} / \mathrm{ml}$ selenium with $20 \mu \mathrm{g} / \mathrm{ml}$ cisplatin (group IV) also increased the levels of ROS in the cells compared with the control group $(\mathrm{P}=0.04612$; Fig. 10).

\section{Discussion}

Recently, several studies have been focused on cisplatin due to its wider uses. Cisplatin induces neurotoxicity, nephrotoxicity, ototoxicity, myelotoxicity, nausea, vomiting, hemolytic anemia and electrolyte disturbances $(6,11)$. Chronic exposure to cisplatin could cause drug resistance and nasopharyngeal cancer. Selenium has attracted attention from several researchers due its anticancer potential (11). The present study demonstrated that chronic exposure to cisplatin could produce nasopharyngeal cancer in adult rats and that the use of selenium could reduce the effect of cisplatin.

The accumulation of free radicals and oxidative stress induction have been reported as the toxic effects of cisplatin (6). It is well known that oxidative stress plays a crucial role in cell apoptosis and death. Increased lipid peroxidation is the primary consequence of this oxidative stress, mainly involving polyunsaturated fatty acids (12). In the present study, cisplatin significantly increased lipid peroxidation in the male albino rats. This is evidence for the role of free radicals and oxidative damage in the reduction of cisplatin-induced nasopharyngeal cancer. Cell membranes may readily bind to cisplatin and cause lipid peroxidation via the increased generation of free radicals (13). Treatment of selenium with cisplatin reduced the concentration of MDA, indicating the anti-cancer activity of selenium (14). It has been reported that the use of selenium has a protective effect against myocardial injury (14).

Cell and tissue integrity and function have been shown to be safeguarded by the protective action of selenium against oxidative damage. ROS may also bind to cellular proteins and can initiate the formation of side chain and readily susceptible (degradative) amino acids (15). Impairment of cell function may occur due to the accumulation of oxidized proteins. Yuan and Tang (16) demonstrated that selenium can counteract the free radicals and oxidative damage in chickens.

The accumulation of free radicals may affect DNA structure and stability, leading to DNA damage and cell death (17). It has been reported that several toxic compounds can induce DNA damage (18), and the lipid peroxidation product MDA could bind to DNA (19). It has been shown that selenium could reduce DNA damage in cells (20). Kara et al (21) have demonstrated the antioxidant properties of selenium. Antioxidant enzymes are the first line of cell defense that safeguards cells from oxidative damage. In the present study, SOD, catalase and LDH activities all significantly increased following selenium treatment.

GSH is a well-known non-enzymatic antioxidant that provides a second line of defense against oxidative damage (22). GSH acts as a substrate for the glutathione peroxidase and glutathione S-transferase enzymes, and is involved in the reduction/removal of ROS from cells (23). Reduced levels of GSH occur during oxidative stress, which results in the impairment of cell function and metabolism (24).
In conclusion, in the present study, cisplatin exhibited carcinogenicity in male albino rats and HK1 cells. Cellular architecture also returned to normal following treatment. Morphological and apoptotic changes confirmed that a reduction in apoptosis occurs following selenium treatment. From these experimental results, it can be concluded that cisplatin could exert carcinogenicity, but that treatment with selenium could significantly reverse this toxicity.

\section{References}

1. Tinggi U: Selenium: Its role as an antioxidant in human health. Environ Health Prev Med 13: 102-108, 2008.

2. El-Demerdash FM and Nasr HM: Antioxidant effect of selenium on lipid peroxidation, hyperlipidemia and biochemical parameters in rats exposed to diazinon. J Trace Elem Med Biol 28: 89-93, 2014.

3. Tinggi U, Reilly $\mathrm{C}$ and Patterson CM: Determination of selenium in foodstuffs using spectrofluorometry and hydride generation atomic absorption spectrometry. J Food Comp Anal 5: 269-280, 1992.

4. Rayman M: Selenium and human health. Lancet 379: 1256-1268, 2012.

5. Brigelius-Flohé R, Banning A and Schnurr K: Seleniumdependent enzymes in endothelial cell function. Antioxid Redox Signal 5: 205-215, 2003.

6. Loehrer PJ and Einhorn LH: Drugs five years later. Cisplatin. Ann Intern Med 100: 704-713, 1984

7. Pandurangan M, Veerappan M and Kim DH: Cytotoxicity of zinc oxide nanoparticles on antioxidant enzyme activities and mRNA expression in the cocultured $\mathrm{C} 2 \mathrm{C} 12$ and 3T3-L1 cells. Appl Biochem Biotechnol 175: 1270-1280, 2015.

8. Muthuraman P, Ramkumar K and Kim DH: Analysis of the dose-dependent effect of zinc oxide nanoparticles on the oxidative stress and antioxidant enzyme activity in adipocytes. Appl Biochem Biotechnol 174: 2851-2863, 2014.

9. Muthuraman P: Effect of cortisol on caspases in the co-cultured C2C12 and 3T3-L1 cells. Appl Biochem Biotechnol 173: 980-988, 2014

10. Muthuraman P, Kim DH, Muthuviveganandavel V, Vikramathithan J and Ravikumar S: Differential bio-potential of $\mathrm{ZnS}$ nanoparticles to normal MDCK cells and cervical carcinoma HeLa cells. J Nanosci Nanotechnol 15: 1-8, 2015.

11. Milosavljevic N, Duranton C, Djerbi N, Puech PH, Gounon P, Lagadic-Gossmann D, Dimanche-Boitrel MT, Rauch C, Tauc M, Counillon L and Poët M: Nongenomic effects of cisplatin: Acute inhibition of mechanosensitive transporters and channels without actin remodeling. Cancer Res 70: 7514-7522, 2010.

12. Windsor RE, Strauss SJ, Kallis C, Wood NE and Whelan JS: Germline genetic polymorphisms may influence chemotherapy response and disease outcome in osteosarcoma: A pilot study. Cancer 118: 1856-1867, 2012.

13. Farber JL, Kyle ME and Coleman JB: Mechanisms of cell injury by activated oxygen species. La Inves 62: 670-679, 1990 .

14. Gan L, Liu Q, Xu HB, Zhu YS and Yang XL: Effects of selenium overexposure on glutathione peroxidase and thioredoxin reductase gene expressions and activities. Biol Trace Elem Res 89: 165-175, 2002.

15. Halliwell B and Gutteridge JMC (eds): Oxidative stress: Adaptation, damage, repair and death. In: Free Radicals in Biology and Medicine. 3rd ed. Oxford University Press, Oxford, pp246-350, 2001.

16. Yuan $\mathrm{X}$ and Tang C: Lead effect on DNA and albumin in chicken blood and the protection of selenium nutrition. J Environ Sci Health A 34: 1875-1887, 1999.

17. Scott D, Galloway SM, Marshall RR, Ishidate M Jr, Brusick D, Ashby $\mathbf{J}$ and Myhr BC: International commission for the protection against environment mutagens and carcinogens. Genotoxicity under extreme culture conditions. A report from ICPEMC task Group 9. Mutat Res 257: 147-205, 1991.

18. Cavalcantea DG, Martinez CB and Sofiaa SH: Genotoxic effects of Roundup on the fish Prochilodus lineatus. Mutat Res 655: 41-46, 2008. 
19. Eder E, Wacker M, Lutz U, Nair J, Fang X, Bartsch H, Beland FA, Schlatter J and Lutz WK: Oxidative stress-related DNA adducts in the liver of female rats fed with sunflowers, rapeseed-, olive- or coconut oil supplemented diets. Chem Biol Interact 159: 81-89, 2006.

20. El-Bayoumy K: The protective role of selenium on genetic damage and on cancer. Mutat Res 475: 123-139, 2001.

21. Kara H, Cevik A, Konar V, Dayangac A and Yilmaz M: Protective effects of antioxidants against cadmium-induced oxidative damage in rat testes. Biol Trace Elem Res 120: 205-211, 2007.
22. Priscilla DH and Prince PS: Cardioprotective effect of gallic acid on cardiac troponin-T, cardiac marker enzymes, lipid peroxidation products and antioxidants in experimentally induced myocardial infarction in Wistar rats. Chem Biol Interact 179: $118-124,2009$

23. Townsend DM, Tew KD and Tapiero H: The importance of glutathione in human disease. Biomed Pharmacother 57: 144-155, 2003.

24. Hill MF and Singal PK: Right and left myocardial antioxidant responses during heart failure subsequent to myocardial infarction. Circulation 96: 2414-2420, 1997. 